\title{
Theorizing Citizenship in Citizen Journalism
}

Vincent Campbell

Department of Media \& Communication

University of Leicester

Bankfield House

132 New Walk

Leicester

LE1 7JA

+44 (0)1162525294

vpc2@le.ac.uk 


\section{ABSTRACT}

Citizen journalism has become a prominent term referring to a variety of newsgathering and reporting practices conducted via a range of new digital technologies. The scholarly literature on citizen journalism, however, has tended to concentrate on its significance for journalism theory and practice whilst comparatively neglecting underlying questions about the theories of citizenship utilized within citizen journalism. This article examines the range of theories of citizenship at work in citizen journalism, highlighting problems in trying to locate citizen journalism practices and practitioners within definitional debates around citizenship. It explores how some theories construct citizen journalism as a tool for citizenship whilst others construct it as constituting a form of citizenship in its own right. The article identifies a range of problems within these theories in terms of their capacity to understand the relationship between citizen journalism and citizenship. It argues that fully understanding and situating citizen journalism requires moving beyond the journalismcentered focus which dominates the literature towards a consideration of citizen journalism that incorporates theories and practices of citizenship alongside those of journalism.

Keywords: Citizenship theory; Journalism studies; Citizen Journalism; Participatory Journalism

Word Count: 7,947 


\section{Introduction}

Citizen journalism has become the dominant term used to describe changes in the global news and journalism landscape whereby ordinary people, outside of traditional news institutions and professions, create, collect, comment on and disseminate news and journalism (Gillmor 2004; Wall 2012). Whilst it might be argued that citizen journalism is simply a convenient label for a range of new journalistic practices, there is a sometimes explicit but often implicit normative dimension to discussions of citizen journalism's contribution to democracy as a result of citizens participating in news production and news flows (Griffiths 2004; Goode 2009; McCauliff 2011; Borger et al. 2013). Yet theories of citizenship in citizen journalism are at best considered at the margins of discussion (Coleman and Blumler 2009; Rosenberry and St. John III 2010; Tewkesbury and Rittenburg 2012) or often not considered at all (Bowman and Willis 2003; Gillmor 2004; Wall 2012). This matters because, as Heater states, citizenship "is more than a label," in which ideas of "identity and virtue invest the concept of citizenship with power" (2004a, 187). Furthermore:

As citizenship is about human relationships, it defies a simple, static definition that can be applied to all societies at all times. Instead, the idea of citizenship is inherently contested and contingent, always reflecting the particular set of relationships and types of governance found within any given society. (Faulks 2000, 6)

Outside of the citizen journalism literature, debates about what constitutes citizenship are a major feature of a significant body of academic literature (Putnam 2000; Annette 2010). Research has challenged idealistic conceptions of citizen behavior in terms of traditional practices of engagement and participation, looking at the variation in both the degree to and means by which people practice their citizenship (Amnå and Ekman 2013; Eveland 2004; Graber 2004; Henn and Foard 2012; Hooghe and Dejaeghere 2007; Hustinx et al. 2012; Livingstone and Markham 2008; Lund 2006; Schudson 1998; Walker 2002), particularly in relation to new media technologies (Bennett et al. 2009; Coleman and Blumler 2012; Gerodimos 2008; Gil de Zúñiga et al. 2012; Ikeda and Boase 2011; Kaufhold et al. 2010; Pasek et al. 2009; Scheufele and Nisbet 2002). Such literature highlights tensions within debates around citizenship, for instance in the distinction between civic and political citizenship (Heater 2004a, 2004b; Theiss-Morse and Hibbing 2005; Annette 2010), revealing that the concept of the citizen is not an uncontested label to simply be tacked onto journalism. This article, therefore, aims to critically interrogate theories of citizenship present within citizen journalism debates. It begins with a brief summary of the journalism-centered debates around citizen journalism before moving on to identify and explore two main problems of citizenship in citizen journalism. First, it considers the problem of identifying and locating the citizen journalist as a citizen through a consideration of some illustrative examples of well-known citizen journalism cases. Second, it explores theoretical approaches to understanding citizenship apparent in the citizen journalism literature, which tends to position citizen journalism as either for citizenship or as citizenship.

\section{Citizen Journalism and Journalism}

The literature on citizen journalism is heavily concentrated on the definitional boundaries of journalistic practice and what it means to be a journalist (see Borger et al. 2013 for a review of such literature). Citizen journalism debates originated primarily around blogging (Lasica 2003; Gillmor 2004), and whilst blogs continue to dominate much citizen journalism output (Meadows 2013), textbased "j-blogs" are now just one part of a raft of online and mobile communication tools being used to produce and disseminate news content, including micro-blogging sites like Twitter and Sina 
Weibo, video sharing sites like You Tube, and social media networks like Facebook. Discussion often focuses on the extent to which material produced by ordinary people amounts to little more than "random acts of journalism" (Lasica 2003, 73) by "accidental journalists" (Allan et al. 2007, 378) or whether they represent new types of journalism and journalists. With each new platform debates are reignited as individual instances of important news events generate fresh discussion on whether their use constitutes journalism or not, as in the case of Sohaib Athar who tweeted about the US Special Forces raid that lead to the killing of Osama Bin Laden (Allan 2013). Debates about the boundaries of journalistic practices are also exacerbated by attempts to retrospectively define a variety of activities and instances of ordinary people making the news as citizen journalism (Meadows 2013), such as the Zapruder footage of the Kennedy assassination (Gant 2007; Allan 2013).

Despite the fact that many practitioners of citizen journalism do not think of themselves as journalists or have journalistic motives (Rettberg 2008; Frölich et al. 2012) the label of journalist and who is entitled to use it is a prominent site of contestation. The debate is divided between those who argue that anyone can be a journalist (Bowman and Wills 2003; Gillmor 2004; Gant 2007), and those who express concerns about the under-valuing of professional skills, training and values in the universal application of the term (Keen 2007; Siegel 2008; Hudson and Temple 2010). Such discussions interrogate the meaning of journalist whilst often leaving the meaning of citizen uncritiqued, as in one early commentator's view that "we're all citizens, but not all of us are journalists" (Safran 2005, 22). More recently, in response to questions about the nature of journalism on "hyper-local" community news sites, one British producer stated:

I think it's a mistake to look at hyper-local sites and see citizen journalism... it's much more fruitful if you look at them and simply see citizens doing what citizens do. It might happen to look a bit like what journalists do - but they have a completely different motivation. (Booth in Radcliffe 2012, 10)

This sentiment reflects an emerging concern within debates on citizen journalism's nature and function, with some wanting to make a clear distinction between citizen journalism on the one hand, seen as an arguably highly political and often privileged position-based type of content, and community reporting on the other, seen as much more about ordinary people focused on their immediate communities (Wilson 2012; Meadows 2013). Such a distinction also relates to concerns surrounding the political economy of citizen journalism such as its co-optation by traditional media organizations (Kperogi 2011), and the extent of its independence from or dependence on mainstream media organizations (Watson 2012). What all these areas of discussion do, however, is focus on the significance of processes, practices and contexts in a journalism-centered manner, with the citizen component of citizen journalism under-discussed.

\section{Locating the Citizen}

It could be argued that the academic focus on the relationship between citizen journalism and journalism is appropriate with the citizen part of the concept having emerged as merely one convenient label alongside other terms such as "participatory journalism" (Bowman and Willis 2003; Frölich et al. 2012; Borger et al. 2013). The problems with the uncritical adoption of the term, however, are that it potentially homogenizes the range of individuals engaged in new journalistic practices and the contexts in which they do so, as well as the underlying theories of what it means to be a "citizen" who engages in journalism. Even within an initial, and relatively simple, definition of citizenship as "a legal status, synonymous with nationality in the modern nation-state" (Heater 
2004b, 115), for instance, problems can be found with trying to locate the citizen in citizen journalism. This can be illustrated by considering the relationship between the geographical and political location of the citizen journalist and the primary focus of their journalism. One of the first citizen journalists to attract global attention, for instance, was the Baghdad blogger "Salam Pax" whose English-language blog during the 2003 Iraq War offered a unique perspective, and one essentially impossible for Western mainstream journalists embedded with coalition armed forces or even Western citizen journalists like Christopher Allbritton (see Allan 2006, 109). Pax's blog became part of the news media landscape in Iraq War journalism, and in the post-war period, Pax produced reports for mainstream Western media. Pax himself agonized over what his blog had become even trying to delete it at one point due to the critical attention it was receiving. In one post he wrote:

I wish there was another Iraqi blogger. I have done a sort of mental exercise on how that weblog would be. To start with it would be in Arabic and discuss as little as possible. If cornered, it would be very pro-Palestinian and pro-Saddam- just to be on the safe side. It would also be filled with quotations from the Koran and Hadith or maybe Um Kalthum songs. What I am trying to say is that most "western" readers wouldn't get it, because it would be so out of their cultural sphere. (Pax in Griffith 2004, 158)

Having spent much of his education in Europe rather than Iraq, Pax later acknowledged this domestic/international tension, commenting "I am this little no one who actually is a kind of a foreigner in his own culture" (Guardian, May 30, 2003). As an act of journalism, Pax's blog proved an early example of "bridge-blogging" (Zuckerman 2008) where a blogger writes for an audience of a different language, culture or nationality to their own but in terms of citizenship it is much harder to simplistically locate. Superficially, Pax's blog offered Western audiences the perspective of an ordinary Iraqi citizen's experiences of the War but the language, attitude and perspective of Pax's blog reflected an individual whose sense of identity and citizenship was at best liminal between Iraq and the West, which in turn may be a crucial factor in what made Pax's blog become so successful with Western audiences.

Another example of a prominent citizen journalist that illustrates this problem of locating the citizen is "Guido Fawkes", one of the most prominent political bloggers in the UK. Fawkes was called as a witness to the 2012 Leveson Inquiry into press standards, set up after widespread evidence of illegal phone hacking by newspaper journalists underpinning a culture of invasive reporting of private lives in the British press. In his testimony to the Inquiry, Fawkes spoke of hosting his blog on servers in the USA to avoid prosecution by British courts, and stated "Something that I think you might have overlooked is that I'm a citizen of a free republic, and since 1922 I don't have to pay attention to what a British judge orders my countrymen to do" (in Leveson Inquiry 2012, 108). Fawkes refers here to his Irish citizenship which he clearly regards as allowing him to circumvent British judicial restrictions on reporting. His case essentially offers the reverse scenario to that of Pax, inverting the bridge-blogger role. Instead of being an internal citizen of a state producing journalism primarily for those outside it, Fawkes is the outsider here- not a citizen of Britain and yet providing journalism predominantly on British politics for British citizens.

The notorious case of the "A Gay Girl in Damascus" blog during the Arab Spring of 2011 further problematizes locating the citizen in citizen journalism. Originally believed to be written by a 35-year old, half-American, half-Syrian gay woman living in Damascus, the English-language blog quickly became a central focus for Western mainstream news media that had little access otherwise to the events in Syria at the time. The level of attention the blog was receiving led its real author, a 40 year old American man named Tom McMaster based in Edinburgh in the UK, to try and close the blog down, only inviting further scrutiny, investigation and subsequent unmasking of his real identity (Bennett 2011). Leaving aside issues here relating to the authenticity or otherwise of citizen journalists' voices and questions of mainstream media's failure to apply critical scrutiny to an online 
source (see Bennett 2011), of significance here is how the case reveals the intrinsic problem of locating citizenship in bridge-blogging and citizen journalism which cuts across geographical and political borders.

The proportion of citizen journalists occupying these kinds of bridging roles is difficult to determine (Zuckerman 2008), and it may be that these high profile cases are not representative of the majority of citizen journalists. Nonetheless, some argue that "much of the rhetoric around citizen journalism is based on activity by a very limited, privileged minority who have access to the means of producing alternative views about the world" (Meadows 2013, 44). Certainly the ability to write fluently and cogently in another language and/or about another culture or political system is hardly a universal or even widespread skill, a key reason for the rise to prominence of figures like Salam Pax in the first place, unquestionably extending the reach of journalism particularly both into and out of states where traditional news media access has been limited. But in terms of these citizen journalists' citizenship status, it is predominantly "still defined by geographical location" (Papacharissi 2010, 108).

Many accounts of citizen journalism tend to omit acknowledgement of the significance of geographical context, however, and as Matheson notes tend to focus on "the technology and with a liberal emphasis on freedom" $(2009,151)$. Its presumed democratic potential undoubtedly dominates the discourse of much of the citizen journalism literature (Borger et al. 2013, 125), but as Matheson argues the presence of citizen journalism in and of itself does "not conjure up an "instant free press", but [places blog] authors in a more complex relationship to the norms and forces of social life" (Matheson 2009, 152). Indeed, it is relatively easy to illustrate how citizen journalists exist in hugely varied contexts. In Iran, for instance, citizen journalists operate in a context where citizenship 'is a problematic concept' (Khiabany and Sreberny 2009, 122) and widespread voting rights are offset against the overarching authority of the clerical elite. Palestinian citizen journalists work according to a different set of restraints within Israeli occupation, restrictions and prohibitions (Allan et al. 2007, 383). In yet another context, secessionists in contested regions of India exercise journalistic freedoms within India's wider democracy whilst at the same time being subject to political and military oppression as a result of their secessionist views (Allan et al. 2007, 379-380). In Saudi Arabia female citizen journalists function within a context of significant limitations of civic and political rights in comparison to Saudi men (Kalil 2011). Citizen journalists in China are widespread too with some, like Zhou Shuguang, having millions of readers dwarfing many of their Western counterparts' reach, but the Chinese state allows and monitors citizen journalist activity in a form of "contracted citizenship" whereby the government has "allowed the Chinese people to have some rights as citizens as long as they [have] affirmed their loyalty to the nation-state" (Gong 2010, 263). In entirely authoritarian states, such as pre-reform Burma the existence of citizen journalism has to be put into the context of the significant political, economic, technological and other constraints limiting who can get access to produce citizen journalism, and the risks and limitations of what they are able to produce, and indeed who it is for (Sandhu 2012, 160).

Location then is far from irrelevant in shaping the spaces of citizenship that citizen journalists occupy, and one can argue further that even in this sense, citizenship is a "dynamic identity" best understood within "what social and political arrangements form the context in which it is practiced" (Faulks 2000,6). Even in mature democracies the principles and practices of citizenship are subject to localized contextual variations. The USA's First Amendment elides the difference between free speech and a free press in ways historically useful to journalists, including to the rise of citizen journalism, but there are still boundaries, particularly in relation to national security as in the cases of Bradley Manning's leaking of military files to Wikileaks (Washington Post, Feburary 21, 2013), and Edward Snowden's leaking of information about NSA surveillance practices (Guardian, February 8, 2013). Beyond national security, the public responsibilities of professions such as teaching often now involve professional codes of practice regarding their use of new media 
(Times Education Supplement, February 26, 2013). An interesting illustration of this comes in the form of police blogs in Britain (Burnett et al. 2012). One of these, "NightJack", received an Orwell award in 2009 and became the focus of a concerted investigation by The Times newspaper to uncover the author's identity, nominally out of a concern over the potential risk of police bloggers writing details of cases which might lead to contempt of court and failed prosecutions. The newspaper eventually unmasked NightJack as a detective constable on the Lancashire police force, Richard Horton, although it subsequently turned out that the newspaper has used illegal hacking techniques in the process of doing so (Guardian, February 8, 2012). Like the cases of Manning and Snowden, the NightJack case highlights this tension of where a citizen's rights and responsibilities lie when citizens' professional roles are in areas of civic importance and they engage in citizen journalism, even within liberal democracies.

\section{Theories of Citizenship}

Citizenship is not only a matter of geographically-bound legal status, indeed as discussed, citizenship defined in that way doesn't reflect or encapsulate the variety and complexity of citizen journalists' circumstances. Instead of focusing on legal status, citizen journalism debates tend to frame citizenship within a variety of often largely implicit, though sometimes explicit, theories of citizenship which can be broadly stored into two groups, those that consider journalism for citizenship and those that consider journalism as citizenship.

\section{Journalism for Citizenship}

As Matheson (2009) noted, a starting presumption for many accounts is that of what we could call the classical model of citizenship within journalism theory which constructs the primary function of citizens as being informed, with the emphasis of this theory on the role of journalists rather than citizens. Gans offers a neat summary of the theoretical position which he argues, in the USA at least "is so widely accepted and thus taken for granted that it is not really discussed" amongst journalism practitioners or scholars $(2003,55)$. He summarizes this classical model as having four components:

(1) [T]he journalist's role is to inform citizens; (2) citizens are assumed to be informed if they regularly attend to the local, national, and international news journalists supply them; (3) the more informed citizens are, the more likely they are to participate politically, especially in the democratic debate that journalists consider central to participation and democracy; (4) the more that informed citizens participate, the more democratic [a state] is likely to be. (Gans 2003, 56)

Gans argues that the first of these elements "seems self-evident" $(2003,56)$ and it is often the starting point for studies of the potential contribution to the production of informed citizens by online news and citizen journalism (e.g. Eveland 2010; Kaufhold et al. 2010). The contention of many commentators here is that the apparent proliferation and diversity of new voices provided by the blogosphere and social media, voices of ordinary people outside of the institutional structures of both traditional political and media power, represents an enhancement of citizenship through increasing the amount and diversity of information available to citizens (McCauliff 2011, 61). Leaving aside the question of whether indeed the blogosphere and social media do provide noticeably distinct forms of information from mainstream media (see Zuckerman 2008; Campbell et al. 2010), the model of the informed citizen is problematic in a number of different ways. 
A central problem of significance for a consideration of citizenship in citizen journalism relates to normative judgments around the amount and nature of information that citizens are supposed to have, and then what the relationship between citizens and that information should be. As Graber points out, in fact "there is no agreement about the scope of citizens' roles or about the subject matter and breadth and depth of information that citizens need to master in order to perform citizenship tasks adequately" (Graber 2004, 560). The informed citizen model is premised, for instance, on an ideal citizen routinely surveying the informational environment around them to keep sufficiently informed to be an effective citizen, and whatever the presumed levels of attention and surveillance, research suggests that "the normative ideal of an informed citizenry is not an empirical reality" (Eveland 2004, 177). Studies of audiences' attention to, understanding and retention of information and knowledge from news has over time shown there to be a significant gap between ideal and reality (Eveland 2004; Graber 2004; Porto 2007), and whilst proponents of citizen journalism have argued that such data indicates limitations in traditional media fulfilling their information role sufficiently which citizen journalism might be better placed to achieve, empirical data on citizen journalism and information provision is equivocal (Kaufhold et al. 2010). Indeed, some argue that the proliferation of information sources in the new media environment make the citizen's task of keeping themselves informed ever more difficult to the point where the traditional informed citizen ideal is simply not viable. Graber asserts this view, stating:

The crux of the counterargument to the claims of deficient media and ill-informed citizens is that the ideal informed citizen type that is at the center of this debate about media and citizen performance simply does not exist and cannot exist in most advanced industrialized societies, especially in large countries. $(2004,561)$

A number of models have been proposed as responses to or alternative conceptions accounting for this problem. Some theories recast the role of the citizen in relation to information as not necessarily linked to other types of citizenship activity, like political participation, such as the conception of "the citizen-spectator" used in Allan's construction of citizen journalism as a form of "citizen witnessing" (Allan 2013). Allan describes the role of citizen spectator as one signifying "a meaningful psychological involvement in current affairs, but not one that translates into active participation in political life" (Allan 2013, 33). Others have suggested shifting the focus from evaluating citizens in terms of whether and to what extent they are informed, and to instead examine their critical faculties for interpreting the information they are able to access, as in Porto's model of the "interpreting citizen" (Porto 2007).

The most prominent of these alternatives to the informed citizen model has been Schudson's conception of the "monitorial citizen" (1998) which features centrally in many discussions of and relating to citizen journalism both within the USA where the concept was formulated and in many other countries (e.g. Graber 2004; Lund 2006; Hooghe and Dejaeghere 2007; Porto 2007; Deuze 2009a, 2009b; Papacharissi 2010; Coleman and Blumler 2012; Hustinx et al. 2012; Tewskbury and Rittenberg 2012). Schudson's conception, rather than seeing the apparently low levels of routine attention to information of civic and political significance as indicative of citizens being uninformed and disengaged, instead suggests that citizens are simply appropriately and strategically selective in what they pay attention to. Graber expands on this by saying that unlike "the fully informed citizens of the prior period, monitorial citizens need not stay fully informed about political developments at all times" (Graber 2004, 562). Instead of constantly trying to remain informed "the monitorial citizen decides to keep his or her surveillance of the political system to a minimum, and decides to intervene only when he or she considers that it is absolutely necessary" (Hooghe and Dejaeghere 2007, 251). Empirical research in this area has centered on the nature of monitorial citizens in terms of the extent and nature of their levels of engagement with information and political participation, with studies in several countries finding evidence of distinct groups of citizens whose engagement and participation is selective (Lund 2006; Hooghe and Dejaeghere 2007; 
Hustinx et al. 2012). Criticism of the monitorial citizen model includes concerns about the passivity of citizens, both in terms of whether the extent and nature of monitorial citizens' selective engagement is sufficient to sustain democracy-for instance in the sense of the extent to which citizens are actually effectively able to understand, interpret and act upon information when only partially engaged- and also whether the model fails to differentiate between different kinds of passivity whereby presumed monitorial or "stand-by citizens" (Amnå and Ekman 2013) who have the desire and capacity to become informed and engaged when they decide to, need to be differentiated from those unwilling or unable to participate.

What is interesting for the discussion here is that the informed citizen, the monitorial citizen and their variants, are essentially reactive models of citizen agency with regard to information and journalism. Citizens are conceived in these theories as people who do things with information in order to enact their citizenship but the production of information itself is not an act of citizenship but an act of journalism. Citizen and journalist in these theories are seen as distinctive rolesjournalism is used by citizens for citizenship, and journalists serve citizens (often in ways which problematize journalists' sense of citizenship). One problem for citizen journalism with the roles of citizen and journalist conceived in this manner is that "engaging in any journalism requires activity, not passivity" (Berger 2011, 712) so citizen journalism creates a tension between a kind of implied passive citizenship in relation to active journalism. Thinking about where the line between citizen and journalist might exist, BBC journalist Stephen Whittle (2005) illustrated this problem in writing about the problem of reporting terrorism and the principle of confidentiality of sources in the wake of the $7 / 7$ London bombings. Writing about the contentious practice of interviewing supporters of terrorism he argued that journalists "have responsibilities as citizens, but our responsibility is also to inform our fellow citizens on the nature of the arguments and threats of which they need to be aware" (Whittle 2005, 57). This comment illustrates one aspect of Berger's (2011) critique of the concept of citizen journalism by indicating that journalists can and do see themselves as citizens. Berger notes that:

Employment by a media house does not cancel out a consciousness of citizenship. The logic here then is that both employed journalists and outsiders can, in this sense, also be regarded as practitioners of "citizen journalism". The other side of the argument here is that one cannot assume that an individual producing public content is necessarily a "citizen" in either fact or consciousness. (2011, 712, emphasis added).

In essence then, the informed and monitorial citizen theories seem to rest on passive conceptions of citizenship in relation to journalism that are problematic for identifying and understanding citizen journalism in two ways. First, the conceptualization of citizens as typically passive surveyors of information, particularly when only on occasion in monitorial models, doesn't offer an explanation for the existence, nature and motivation of citizens who are actively producing information. Citizen journalists are not simply spectators or on stand-by, they are actively producing content, so these theories fail to make sense of these individuals doing something above and beyond conventional citizen activity. Second, the possibility of mainstream journalists conceiving of themselves as citizens muddies any attempt to clearly distinguish between mainstream and citizen journalism as well as undermining presumptions about the producers of citizen journalism actually being citizens.

\section{Journalism as Citizenship}

Another set of theories of citizenship that emerge in relation to citizen journalism focus on different aspects of citizen identity and activity to those of the informed/monitorial citizen type models. Whilst some of these conceptions directly address problems in the informed/monitorial citizen models, they nonetheless contain their own problems in the specific context of making sense of citizenship in citizen journalism. In different ways essentially these theories view citizen journalism not as a resource for citizenship but as directly constituting citizenship. 
The discussion thus far in this article has centered on citizenship primarily in terms of legal status linked to the nation-state but debates around citizenship are not restricted to legal status definitions. As noted by Berger above $(2011,712)$ a sense of citizenship, in terms of consciousness and identification may be present regardless of legal status, and it is in terms of citizenship as a form of subjective and changing citizen identity that the role of the media is potentially significant, as in the notion of "cosmopolitan communications" and the possible spread of global civic values (Norris and Inglehart 2009; Deuze 2009b). Papacharissi uses the phrase "liquid citizenship" to describe how "as individuals assume lifestyles that fluidly transfer them through a variety of locations and/or require that they develop everyday interactional routines with individuals and organizations around the world, the conceptual periphery of civic, political, and social is remapped" $(2010,109)$. Such notions seem to account for the presence of citizen journalism and bridge-bloggers in the wide range of national contexts mentioned earlier, although the activities of such citizen journalists seem in these conceptions to be more about the construction and maintenance of individual citizen identities than about journalism. Take, for example, McCauliff's articulation of the significance of blogs like "Baghdad Burning" written by an Iraqi woman under the pseudonym "Riverbend":

Women are able to claim cyberspace for their expressions of individuality and desire for freedom. On the internet, a young, independent woman can carve out a space that is free from the politically manipulated world she may inhabit. Or she may perform independence even when she is not. The internet, then, is a site where some Muslim women, such as Riverbend, can articulate their identities and political experiences. (McCauliff 2011, 63).

This corresponds to the conception of citizenship in radical democracy theory as a form of identity rather than a legal status, and one which requires citizens to "actively participate in actions that shape their own identities" (Rodriguez 2001, 19). This formulation takes the notion of citizenship identity a stage further:

Seen from a radical democracy perspective, citizens' media materialize as important sites where citizenship is forged. By participating in these media experiences, reshaping their identities, reformulating established social definitions, and legitimizing local cultures and lifestyles on the personal as well as the local level, communities are actively enacting citizenship. (Rodriguez 2001, 158)

Whilst Rodriguez's conception of citizen's media is not synonymous with citizen journalism, referring more to collective community-based initiatives, the conception of citizenship within it is paralleled in accounts of citizen journalism like McCauliff's above.

An alternative approach considers the relationship between citizens and modes of participation, finding in the informed/monitorial theories an over-concentration on traditional modes of citizenship like voting, and surveying the mainstream news. This alternative theory posits a distinction between what are called "dutiful" citizens, who engage in traditional citizenship practices, and "actualizing" citizens who conduct their citizenship in a variety of non-traditional ways such as political consumerism (Bennett et al. 2009, 107; Hustinx et al. 2012). Within this model the idea is that actualizing citizens are a lot less likely to use traditional media, and much more likely to use online and social media as sources of information, discussion and participation (Bennett et al. 2012). In this sense then, citizen journalism becomes a potentially important resource for actualizing citizens in terms of both information provision and information production, although few studies have explored this relationship in detail and those that have offer skepticism over the significance of media for functioning in this way (Livingstone and Markham 2008).

Critiques of approaches that essentially regard citizen journalism as citizenship, center on a number of aspects. Thinking first about the idea of citizen journalism as a space for people to construct and articulate their citizen identity, the problem here is a concern over the degree of 
individualization, personalization and ego-driven content in citizen journalism. One study of participants in a German citizen journalism exercise found that many of the reasons behind people's participation in the project were not civic-minded, stating that many of their "motives [were] basically self-centered, such as individually perceived creativeness, the fascination of publishing and the enjoyment of presenting one's own ideas to a larger public" (Fröhlich et al. 2012, 1056). Another study in the USA found that a key motive for blogging is "personal fulfilment" (Kaye 2007, 137), and some have described blogging specifically as a new form of "narcissism" (Papacharissi 2010, 144; Markham 2010, 86). The combination of self-reflection and self-expression in blogging narcissism may be consequentially positive for democracy through providing a plurality of voices (Papacharissi 2010,148 ) though others argue that the focus on individual subjectivity undermines their democratic potential (Markham 2010, 87). Either way blogs' "function is expressive first, and deliberative only by accident," and "should not be mistaken for journalism" (Papacharissi 2010, 149). Moreover, citizen journalist roles in this sense are a relatively narrow, privileged group (Meadows 2013), seen as having the confidence to be self-contained operators or "self-referrers" (Wilson 2012, 4) and having skills that significant sections of the population lack (Bennett et al. 2009, 115). Both what kind of citizen is being referred to in citizen journalism and the nature of the journalism produced, are thus complicated rather than simplified through appeals to citizenship identity as an on-going individual construction.

Proponents of citizen journalism within such conceptions argue that the mere expression of alternative voices, perspectives and identities constitute a contribution to citizenship through the production of oppositional content (Papacharissi 2010, 149). As in the claims made for citizen's media (Rodriguez 2001), so others have claimed the same possibility for citizen journalism, arguing that their impact can amount to a kind of "minimal politics" where the impact may not be on political decision-making or decision-makers but on the wider discourse in a topic area (Macgilchrist and Böhmig 2012), and "challenging the established public agenda" (Papacharissi 2010, 148). The problem here is seeing the production of, or contribution to, online content as an end in itself, since as Markham notes interaction "in itself is of no political value if that interaction [...], "doesn't go anywhere"'" (Markham 2010, 78). Others have argued that practices like citizen journalism and contributing to online discussion forums, or online spaces set up for public participation, risk slipping into "participationism" or participating for the sake of participating (Gerodimos 2008, 983), and may amount to a kind of "interpassivity" (Dean 2005, 60) where all that is happening is people contributing to the circulation of content online. Again, the idea that citizen journalism is somehow enacting citizenship- or indeed even serving citizenship- through the provision of deliberation is highly questionable. As the police blogger "NightJack" referred to earlier in the article stated in his blog:

I don't know if blogging changes anything. I do know that I am just a short lever in this world but it was worth a go on the off chance that there were people reading that could deploy longer levers. (5 April 2009). (in Burnett et al. 2012, 59)

Like other UK police bloggers included in their study Burnett et al. found that rather than looking for deliberation or discussion, a primary motive was simply "venting" frustration $(2012,59)$.

A final critique of these approaches to citizen journalism brings into question the legitimacy of the range of alternative practices of citizenship identified by models such as that of the actualizing citizen. Critics of these notions of differential modes of citizenship point to the problematic separation of civic and political activities in relation to citizenship stemming from Putnam's notion that civic participation and engagement could be fostered through encouraging people to participate in things like volunteering and charity work (2000). As Theiss-Morse and Hibbing pithily observe the "added allure was that citizens would not need to do anything particularly distasteful in the process, such as becoming involved in politics" $(2005,228)$. The presumption was that increased civic 
participation would increase wider political participation but the problem is that most "volunteer work is considered by volunteers to be non-political" (Keeter et al. 2002, 19). In one study of volunteering and service work, participants clearly saw a difference between civic and political participation. It was evident that when confronted with "any talk of political engagement-voting, running for office, lobbying - [...] they recoiled with disgust. Service was a friendly, morally pure alternative to the messy, dirty, compromise-filled world of politics" (Walker 2002, 183). In this sense, considering citizen journalism as an alternative form of participation along the lines of activities like volunteering as some discussions of community reporting do (Wilson 2012; Meadows 2013), raises the question of its relationship to "the important distinction that should be made between volunteering which leads to active citizenship and a more political form of civic engagement in the community which can lead to democratic citizenship" (Annette 2010,131) and thus whether citizen journalism as participation can be legitimately regarded as a form of civic and/or political citizenship.

\section{Conclusion}

Discussions of citizen journalism have, thus far, been heavily focused on theories and practices of journalism, leaving theories and practices of citizenship at best marginalized or elided even though citizen journalism debates often focus on the democratic implications of citizen journalism (Borger et al. 2013). As this article has shown, new practices and practitioners generate significant challenges for locating and theorizing the dynamic and multi-faceted forms of citizenship at work within citizen journalism. It is questionable whether the range of theories utilized in current citizen journalism debates both explicitly and more frequently implicitly and without critical scrutiny, are actually able to effectively capture and understand the range of practitioners and practices evident in contemporary citizen journalism. Only through a closer consideration of theories and practices of both citizenship and journalism will a fuller understanding of citizen journalism and its significance emerge, including a fuller consideration of the legitimacy of the term itself. 


\section{Bibliography}

Allan, Stuart 2006. Online News. Maidenhead: Open University Press.

Allan, Stuart. 2013. Citizen Witnessing. Cambridge: Polity.

Allan, Stuart, Prasun Sonwalkar, and Cynthia Carter. 2007. "Bearing Witness: Citizen Journalism and Human Rights Issues." Globalisation, Societies and Education 5 (3): 373-389.

Amnå, Erik, and Joakin Ekman. 2013. "Standby Citizens: Diverse Faces of Political Passivity." European Political Science Review June pp: 1-21.

Annette, John. 2010. "Democratic Citizenships and Lifelong Active Learning." In Active Citizenship: What Could it Achieve and How?, edited by Bernard Crick and Andrew Lockyer, 129-136. Edinburgh: Edinburgh University Press.

Bennett, Daniel. 2011. "A 'Gay Girl in Damascus', the Mirage of the 'Authentic Voice' and the Future of Journalism." In Mirage in the Desert? Reporting the Arab Spring edited by John Mair and Richard L. Keeble,187-195. Bury St. Edmunds: Abramis.

Bennett, W. Lance, Deen G. Freelon, Muzammil M. Hussain, and Chris Wells. 2012. "Digital Media and Youth Engagement." In The Sage Handbook of Political Communication, edited by Holli A. Semetko and Maggie Scammell, 127-140. London: Sage.

Bennett, W. Lance, Chris Wells, and Allison Rank. 2009. "Young Citizens and Civic Learning: Two Paradigms of Citizenship in the Digital Age." Citizenship Studies 13 (2): 105-120.

Berger, Guy. 2011. "Empowering the Youth as Citizen Journalists: A South African Experience." Journalism 12 (6): 708-726.

Borger, Merel, Anita van Hoof, Irene C. Meijer, and José Sanders. 2013. "Constructing Participatory Journalism as a Scholarly Object." Digital Journalism 1 (1): 117-134.

Bowman, Shayne, and Chris Willis. 2003. "We Media. How Audiences Are Shaping the Future of News and Information." The Media Center at the American Press Institute.

http://www.hypergene.net/wemedia/download/we_media.pdf.

Burnett, Simon, Sarah Pedersen, Robert Smith, and Anne O'Neil. 2012. "Venting, Joining and Education: Motivations for Knowledge Sharing in the UK Police Blogosphere." Business Information Review 29 (1): 57-63.

Campbell, Vincent, Rachel Gibson, Barrie Gunter, and Maria Touri. 2010. "News Blogs, Mainstream News and News Agendas." In Web Journalism:// A New Form of Citizenship?, edited by Sean Tunney and Garrett Monaghan, 29-45. Brighton: Sussex Academic Press.

Coleman, Stephen. and Blumler, Jay.G. 2009. The Internet and Democratic Citizenship: Theory, Practice and Policy. Cambridge: Cambridge University Press.

Coleman, Stephen, and Blumler, Jay.G. 2012. "The Internet and Citizenship: Democratic Opportunity or More of the Same?" In The Sage Handbook of Political Communication, edited by Holli A. Semetko and Maggie Scammell, 141-152. London: Sage.

Dean, Jodi. 2005. "Communicative Capitalism: Circulation and the Foreclosure of Politics." Cultural Politics 1 (1): 51-74. 
Deuze, Mark. 2009a. "Journalism, Citizenship and Digital Culture." In Journalism and Citizenship: New Agendas in Communication, edited by Zizi Papacharissi, 15-28. London: Routledge.

Deuze, Mark. 2009b. "The Future of Citizen Journalism." In Citizen Journalism: Global Perspectives, edited by Stuart Allan and Einer Thorsen, 255-264. New York: Peter Lang.

Eveland Jr., William P. 2004. "The Effect of Political Discussion in Producing Informed Citizens: The Roles of Information, Motivation, and Elaboration." Political Communication 21 (2): 177-193.

Faulks, Keith. 2000. Citizenship. London: Routledge.

Frölich, Romy, Oliver Quiring, and Sven Engesser. 2012. "Between Idiosyncratic Self-interests and Professional Standards: A Contribution to the Understanding of Participatory Journalism in Web 2.0. Results from an Online Survey in Germany." Journalism 13 (8): 1041-1063.

Gant, Scott. 2007. We're All Journalists Now. New York: Free Press.

Gans, Herbert J. 2003. Democracy and the News. London: Oxford University Press.

Gerodimos, Roman. 2008. "Mobilising Young Citizens in the UK: A Content Analysis of Youth and Issue Websites." Information, Communication \& Society 11 (7): 964-988.

Gil de Zúñiga, Homero, Nakwon Jung, and Sebastián Valenzuela. 2012. "Social Media Use for News and Individuals' Social Capital, Civic Engagement and Political Participation." Journal of ComputerMediated Communication 17: 319-336.

Gillmor, Dan. 2004. We the Media. Grassroots Journalism by the People, for the People. Sebastopol, CA: O'Reilly.

Gong, Qian. 2010. “Facilitating Participatory Communication in China: An Analysis of Citizen Journalists and Media Regulators in the Qiangguo Forum and its Discussions on Income Inequality." In Web Journalism:// A New Form of Citizenship?, edited by Sean Tunney and Garrett Monaghan, 261-274. Brighton: Sussex Academic Press.

Goode, Luke. 2009. "Social News, Citizen Journalism and Democracy." New Media and Society 11 (8): 1287-1305.

Graber, Dorothy. 2004. "Mediated Politics and Citizenship in the Twenty-First Century." Annual Review of Psychology 55: 545-71.

Griffiths, Mary. 2004. "e-Citizens: Blogging as Democratic Practice." Electronic Journal of eGovernment 2 (3): 156-166.

Heater, Derek. 2004a. Citizenship: The Civic Ideal in World History, Politics and Education. $3^{\text {rd }}$ edition. Manchester: Manchester University Press.

Heater, Derek. 2004b. A Brief History of Citizenship. Edinburgh: Edinburgh University Press.

Henn, Matt, and Nick Foard. 2012. "Young People, Political Participation and Trust in Britain." Parliamentary Affairs 65: 47-67.

Hooghe, Marc, and Yves Dejaeghere. 2007. "Does the 'Monitorial Citizen' Exist? An Empirical Investigation into the Occurrence of Postmodern Forms of Citizenship in the Nordic Countries." Scandinavian Political Studies 30 (2): 249-271. 
Hudson, Gary, and Temple, Mick. 2010. "We are Not All Journalists Now". In Web Journalism:// A New Form of Citizenship?, edited by Sean Tunney and Garrett Monaghan, 63-76. Brighton: Sussex Academic Press.

Hustinx, Lesley, Lucas C.P.M. Meijis, Femida Handy, and Ram A. Cnaan. 2012. "Monitorial Citizens or Civic Omnivores? Repertoires of Civic Participation Among University Students." Youth and Society 44 (1): 95-117.

Ikeda, Ken'ichi, and Jeffrey Boase. 2011. "Multiple Discussion Networks and their Consequence for Political Participation." Communication Research 38 (5): 660-683.

Kalil, Ashraf. 2011. “Blog On.” Index on Censorship 40 (1): 141-145.

Kaufhold, Kelly, Sebastián Valenzuela, and Homero Gil de Zúñiga. 2010. “Citizen Journalism and Democracy: How User-Generated News Use Relates to Political Knowledge and Participation" Journalism and Mass Communication Quarterly 87 (3/4): 515-529.

Kaye, Barbera.K. 2007. "Blog Use Motivations: An Exploratory Study." In Blogging, Citizenship and the Future of Media, edited by Mark Tremayne, 127-148. London: Routledge.

Keen, Andrew. 2007. The Cult of the Amateur. London: Nicholas Brealey.

Keeter, Scott, Cliff Zukin, Molly Andolina, and Krista Jenkins. 2002. The Civic and Political Health of the Nation: A Generational Portrait. Medford, MA: CIRCLE.

Khiabany, Gholam, and Annabelle Sreberny. 2009. "The Iranian Story: What Citizens? What Journalism?" In Citizen Journalism: Global Perspectives, edited by Stuart Allan and Einar Thorsen, 121-132. New York: Peter Lang.

Kperogi, Farooq A. 2011. "Cooperation with the Corporation? CNN and the Hegemonic Co-optation of Citizen Journalism through iReport.com." New Media \& Society 13 (2): 314-329.

Lasica, J.D. 2003. "Blogs and Journalism Need Each Other." Nieman Reports Fall pp: 70-74.

Leveson Inquiry. 2012. "Transcript of Morning Hearing $8^{\text {th }}$ February 2012."

http://www.levesoninquiry.org.uk/wp-content/uploads/2012/02/Transcript-of-Morning-Hearing-8February-2012.pdf.

Livingstone, Sonya, and Tim Markham. 2008. "The Contribution of Media Consumption to Civic Participation." The British Journal of Sociology 59 (2): 351-371.

Lund, Anker B. 2006. "Domesticating the Simpsons- Four Types of Citizenship in Monitorial Democracy." MedieKultur: Journal of Media and Communication Research 22 (40): 15-25.

Macgilchrist, Felicitas. and Inse Böhmig. 2012. "Blogs, Genes and Immigration: Online Media and Minimal Politics." Media, Culture \& Society 34 (1): 83-100

Markham, Tim. 2010. "The Case against the Democratic Influence of the Internet on Journalism." In Web Journalism:// A New Form of Citizenship?, edited by Sean Tunney and Garrett Monaghan, 7794. Brighton: Sussex Academic Press.

Matheson, Donald. 2009. "What the Blogger Knows." In Journalism and Citizenship: New Agendas in Communication, edited by Zizi Papacharissi, 151-165. London: Routledge.

Meadows, Michael. 2013. "Putting the Citizen back into Journalism." Journalism 14 (1): 43-60. 
Norris, Pippa, and Ronald Inglehart. 2009. Cosmopolitan Communications: Cultural Diversity in a Globalized World. Cambridge: Cambridge University Press.

Papacharissi, Zizi. 2010. A Private Sphere: Democracy in a Digital Age. Cambridge: Polity.

Pasek, Josh, Eian More, and Daniel Romer. 2009. "Realizing the Social Internet? Online Social Networking Meets Offline Civic Engagement." Journal of Information Technology \& Politics 6 (3-4): 197-215.

Porto, Mauro.P. 2007. "Frame Diversity and Citizen Competence: Towards a Critical Approach to News Quality." Critical Studies in Media Communication 24 (4): 303-321.

Putnam, Robert. 2000. Bowling Alone: The Collapse and Revival of American Community. New York: Simon and Schuster.

Radcliffe, Damian. 2012. "Here and Now: UK Hyperlocal Media Today." London: NESTA. http://www.nesta.org.uk/library/documents/Here_and_Now_v17.pdf.

Rettberg, Jill W. 2008. Blogging. Cambridge: Polity Press.

Rodríguez, Clemencia. 2001. Fissures in the Mediascape. An International Study of Citizens'Media. Cresskill, NJ: Hampton Press.

Safran, Steve. 2005. "How Participatory Journalism Works." Nieman Reports Winter pp: 22-24.

Scheufele, Dietram A., and Matthew C. Nisbet. 2002. "Being a Citizen Online: New Opportunities and Dead Ends." International Journal of Press/Politics 7 (3): 55-75.

Schudson, Michael. 1998. The Good Citizen: A History of American Civic Life. Cambridge, MA: Harvard University Press.

Siegel, Lee. 2008. Against the Machine. London: Serpent's Tail.

Tewksbury, David, and Jason Rittenberg. 2012. News on the Internet: Information and Citizenship in the 21st Century. Oxford: Oxford University Press

Theiss-Morse, Elizabeth, and John R. Hibbing. 2005. "Citizenship and Civic Engagement." Annual Review of Political Science 8: 227-249.

Walker, Tobi. 2002. "Service as a Pathway to Political Participation: What Research Tells Us." Applied Developmental Science 6 (4): 183-188.

Wall, Melissa. ed. 2012. Citizen Journalism: Valuable, Useless or Dangerous?. New York: International Debate Education Association.

Watson, Hayley. 2012. "Dependent Citizen Journalism and the Publicity of Terror." Terrorism and Political Violence 24 (3): 465-482.

Whittle, S. (2005) 'Journalists as Citizens', British Journalism Review, 16(4): 54-57.

Wilson, Teresa. 2012. "Community Reporting and Citizen Journalism: A Venn Diagram." Institute of Community Reporters. http://testmcin.files.wordpress.com/2012/06/community-reporting-vscitizen-journalism.pdf retrieved 19/11/12.

Zuckerman, Ethan. 2008. "Meet the Bridgebloggers." Public Choice 134 (1/2): 47-65. 